\title{
Agricultural Land Management Based On Local Arisival Of The Kaili Da'a Tribe In Dombu Village
}

\author{
Juraid Abdul Latief *1, Wahyuni ${ }^{2}$, Ika Listiqowati ${ }^{3}$ \\ Jurusan Pendidikan Ilmu Pengetahuan Sosial, Universitas Tadulako \\ ${ }^{*}$ Corresponding author \\ E-mail: juraidalatief@yahoo.com
}

\begin{abstract}
.
This study aims to describe the local wisdom of the Kaili da'a Tribe in managing agricultural land in Dombu Village, Marawola District, Sigi Regency, Central Sulawesi. This research is descriptive qualitative, the research subjects in this study are the people of the Kaili da'a Tribe in Dombu village with the key informant of the Kaili da'a tribal chief, the types and sources of data are primary data and secondary data with data collection methods through observation and interviews. Qualitative descriptive data analysis technique. The results of this study indicate that the cultivation of agricultural land is carried out traditionally in accordance with the local wisdom of the Kaili da'a Tribe, while the management of agricultural land of the Kaili da'a Tribe includes: 1) Preparation includes customary council meetings and traditional ceremonies, 2) Land Opening, 3) Plowing of Land, 4) Land Harvesting, 5) Basic Fertilization.
\end{abstract}

Keywords: Agricultural, Local Wisdom, Kaili da'a Tribe

\section{INTRODUCTION}

The land is one of the most important natural resources for humans, considering human needs both for sustaining their lives and activities of their socio-economic and socio-cultural life [1]. The land is also a system consisting of various components in which there are land characteristics and land quality [2]. Land as a natural resource supports various human activities and provides space for human survival, therefore its sustainability must be considered to meet long-term needs. One of the most important lands uses in meeting needs is the use of land for agriculture. Agricultural land is an important part of agriculture. Agricultural land is land used for agricultural activities as a medium or place to grow crops or cultivate livestock. Agricultural land management is an important and main step that must be considered before planting crops, agricultural land management is closely related to soil fertility. Therefore, agricultural land management must be carried out carefully by the principles of correct and environmentally friendly land management [3]. Changes in times and modernization have made the needs more diverse and numerous. In addition, the high population growth rate demands agricultural production to become more numerous, diverse, and faster, to meet these demands can make management of agricultural land resources unwise. Problems that then arise include clearing agricultural land by burning it, using chemical fertilizers and pesticides excessively. This has resulted in a decline in the quality of agricultural land resources, which it is feared will reduce the level of agricultural productivity, eventually decreasing food security [4]. In addition, it can cause environmental pollution and have an impact on environmental damage. Therefore, agricultural land use activities must be wise and prudent towards the natural environment, so it is necessary to cultivate agricultural land that is correct, environmentally friendly, and supports food security. One of the effective ways to overcome this problem is by using local wisdom.

Various views explain local wisdom, but basically, local wisdom refers to community values and natural balance. Local wisdom can be understood as a human effort by using their intellect to act and behave towards 
something, object, or event that occurs in a certain space. Local wisdom is the values that apply in a community, values that are believed to be true and become a reference in the daily behavior of the local community. Local wisdom Reflected in the long-standing habits of community life. This sustainability is reflected in the values prevailing in certain groups of society. These values are held by certain groups of people, which are usually an inseparable part of life. Local wisdom is an attempt to find the truth based on facts or symptoms that apply specifically in a certain culture [5]The Kaili tribe is an indigenous ethnic group from Central Sulawesi Province, the Kaili tribe or the Kaili ethnic group is divided into 30 ethnic groups, such as the Kaili Rai family, the Kaili Ledo family, the Kaili Ija family, the Kaili Moma family, the Kaili da'a family, the Kaili Unde family, the Kaili Unde family, Kaili Inde, Kaili Tara family, Kaili Bare'e family, Kaili Doi family, Kaili Torai family, etc. There are several opinions that explain the origin of the word Kaili, one of which is that the word Kaili comes from the name of the Kaili tree and fruit that grows in forests in Central Sulawesi, especially on the banks of the Palu River and Palu Bay [6].The focus of this research study is the Kaili da'a Tribe. The Kaili da'a tribe maintains harmony and social order between humans and humans, between humans and their environment, and between humans and their ancestors. Da'a means no, some people interpret this definition as an attitude of rejection of colonialism. The Kaili da' $a$ tribe has unwritten rules but they are understood and obeyed to create harmony. Regulations contained in customary law are divided into forms of belief, life cycle, livelihood system, language, arts, organization, social governance and others [7]. Dombu Village is one of the villages in the West Marawola sub-district, Sigi Regency, Central Sulawesi Province. Dombu Village is located in the mountainous area of Gawalise with an altitude of $1300 \mathrm{~m}$ above sea level, and has an area of 42 kilometers square [8]. Dombu Village is a research focus area because the Kaili da'a Tribe who lives in Dombu Village is the center of the Kaili da' $a$ Tribe and has an advanced level of agriculture, but is environmentally friendly, besides that the people in Dombu Village easily communicate using Indonesian. Every problem or case that exists in the Kaili da' $a$ Tribe is resolved according to custom in Dombu Village because Dombu Village is the center of the Kaili da'a Tribe. In addition, the Head of Dombu Village, Mr. Andi Lasipi, is the traditional leader of the Kaili da'a Tribe who lives in Dombu Village.

The Kaili $d a^{\prime} a$ tribe generally works as farmers. Some agricultural produce is sold in the city. In addition, the Kaili da'a tribe in fulfilling their daily needs is obtained through bugis traders who come to their village, either from mobile traders or traders in the market. The youth of the Kaili da'a tribe who have been to the city generally work as coolies, pedicab drivers or traditional market laborers in the city of Palu and its surroundings [8].The interesting and unique thing about the Kaili $d a^{\prime} a$ tribe is that they believe that the surrounding environment is controlled by spirits called pue or wiyata or anitu or gods both in the forest, on land and water. The whole universe is guarded by puesuwa. With the existence of gods who guard the environment, everyone who will manage the environment must be careful and ask permission through traditional ceremonies so that the gods do not get angry. The forest environment is guarded by wood guards, namely Puenggayu or the wood god called Anitu Larangkayu. Then the wood god consists of 3 types, namely Dewa Yalarawa who guarded the top of the tree, Dewa Dandia who guarded the middle of the tree, Dewa Suluvaeni who guarded the bottom of the tree [13]. From this belief, if you are going to cut trees you must ask permission from the customary leader and comply with the rules or requirements. Likewise, in the case of clearing forests, it is mandatory to ask permission from the customary leader and follow the applicable rules, one of which is to conduct a traditional ceremony. In the land environment, there is also a god who rules the land. According to the belief of the people of the Kaili da' $a$ Tribe, this god can appear and transform into an animal called a Kalomba (resembling a goat) if someone throws out coconut waste in the afternoon [13]. So throwing garbage, especially coconut dregs on the ground in the afternoon is taboo. This belief makes the Kaili da'a Tribe refrain from doing damage to natural resource management, including in terms of agricultural land management. So every step in the management of agricultural land is carried out carefully and environmentally friendly to create a natural balance. 


\section{METHODS}

This type of research is descriptive qualitative [9]. The research location is located in Dombu Village, West Marawola District, Sigi Regency, Central Sulawesi Province. Types of data and data sources in this study are primary data and secondary data. Primary data in this study are the results of interviews obtained from informants (traditional leaders). Secondary data includes Books and journal articles. The research subjects were the people of the Kaili da'a Tribe, and the key informant was the Kaili da'a tribal chief. Data Collection Techniques: Literature study, observation and interviews. The things that were observed were the stages and methods of managing the agricultural land of the Kaili $d a a^{\prime} a$ Tribe. The interviews were conducted using in-depth interviews, namely interviews aimed at key informants to find out the local wisdom of the Kaili da' $a$ Tribe in managing agricultural land and the values upheld by the Kaili da'a Tribe are related to the management of agricultural land. The data analysis technique in this study is a qualitative descriptive analysis.

\section{RESULTS AND DISCUSSION}

West Marawola District is a highland area that is entirely mountainous and is located at an altitude of 150-1,350 $\mathrm{m}$ above sea level. The village that has the highest altitude above sea level is Dombu Village which is also the capital of West Marawola District with an altitude of 1,350 masl. Meanwhile, the village that has the lowest altitude above sea level is Matantimali Village with an altitude of 150 masl. The climatic conditions of Dombu Village are included in the temperate climate zone, with an altitude between 600 - 1500 masl. The average temperature is between $17.1^{\mathrm{oC}}$ to $22^{\mathrm{oC}}$. This condition is very suitable for plantations or vegetable and fruit farming [10].Humans and the natural environment are a relationship of two components that influence each other as a system. This system can cause a cause and effect. Humans as components who can master science and technology can master nature according to their needs and can act or behave by natural conditions. In other words, humans can adapt to natural conditions. However, the human population is increasing causing human needs to increase, become more diverse, and the time for meeting needs is getting faster. These things can lead to the exploitation of nature, one of which is the management of agricultural land that is not by the correct rules. Such as excessive use of chemical fertilizers, excessive use of pesticides, and clearing of agricultural land without paying attention to nature conservation can result in disasters and environmental damage. So to protect the environment from damage due to natural exploitation can be done through local wisdom. Why local wisdom, it is because local wisdom is a wise and wise act by local conditions. This local wisdom is a policy that is carried out and obtained from generation to generation from the ancestors to meet needs adapted to the natural conditions of the local environment. Therefore local wisdom becomes a strong fortress to minimize and prevent natural damage.

This is like research on local wisdom carried out by Dewi Liesnoor Setyowati et al (2019) who examines local wisdom of farmers on conservation agricultural land in the Dieng area. The local wisdom related to land conservation in Dieng Kulon consisted of the making of non-mulch beds, the use of day-related myths, such as jumat kliwon or selasa kliwon, the use of wind to determine the season, and the use of manure. From this explanation, it can be seen that local wisdom has traditional values, belief values that are believed by local people, are maintained and implemented from generation to generation to maintain the balance of nature wisely and wisely [11].Other research conducted by Kadhung Prayoga (2016) is local wisdom in managing peatlands that are used by farmers as a reference in managing agricultural land, local wisdom in managing peatlands, among others: (1) the use of tidal movements for water irrigation and drainage, (2) determination of plants planted around the waters, (3) water conservation with a tebat system (4) land selection system (5) land preparation and soil processing systems (6) land management system (7) soil fertility management system, and (8) how farmers recognize seasons. "From this research, it can be seen that local wisdom can solve local problems related to land management, in this case, peatlands. From these two studies, it can prove that problems that exist in an area can be resolved by the local wisdom of the area itself. So local wisdom in an area is an 
alternative solution to the problems faced in the region itself. In effect, previous people, ancestors, or ancestors have read natural phenomena, understand local natural conditions, and can meet needs by adjusting local natural conditions, and can solve problems with local wisdom [12].Similar to the Kaili da'a tribe who live in Dombu Village, they have unique local wisdom and are suitable to be applied in the local area (local) to control damage to agricultural land. The life of the Kaili da'a tribe is still closely related to local wisdom, especially in terms of agricultural land management that still maintains customary laws, belief in gods and ancestral spirits so that they can control agricultural activities to be environmentally friendly. The Kaili da'a tribe believes that the natural environment is a part of themselves, so they should not destroy nature, especially in agricultural land management activities.

The Kaili da'a tribe has two understandings of the forest, namely the first is Olo, which is a sacred forest, and the second is Pangela, which is a forest that has not been touched. Olo is a sacred forest so it cannot be entered carelessly because according to them the forest is guarded by the spirit of the forest ruler, if it is violated then the person cannot get out of the forbidden forest. So the forest has been preserved until now. The principle of the Kaili $d a^{\prime} a$ tribe is that the environment is an asset for the welfare of indigenous peoples, including in the management of agricultural land. So that their attitudes and behavior towards the environment are equal relations and have a sustainable management system. The Kaili da'a tribe in Dombu Village is a relationship between communities that inhabit the coalition area with its nature reflected in the philosophy of life that was passed down from generation to generation where the philosophy of life reads Tanah Indoku-Ummaku Langi (Land is my mother and the sky is my father). This relationship explains that the principle of the Kamalisi customary community includes the Kaili $d a^{\prime}$ a tribal people who think that land is a natural resource that is very important in providing life. Almost all human needs are caused by the land, that in its creation, humans are made of soil and will return to land [13].From the principles of the Kaili da'a Tribe, it is forbidden for him to manage agricultural land that is against the rules of customary law and the values adhered to by the Kaili da' $a$ Tribe. So it includes how to manage agricultural land which is carried out in an organic and environmentally friendly manner, to support the existence of soil fertility. The local wisdom of the Kaili da'a Tribe in managing agricultural land is as follows:

\section{1) Preparation}

The first activity to cultivate the agricultural land of the Kaili $d a^{\prime} a$ Tribe of Dombu Village was preparation. As for who prepared as follows: a) Customary council meeting, the people of the Kaili da' $a$ tribe in Dombu Village always hold a customary council meeting. One of them is agricultural land management. To determine agricultural land to be cultivated, you must ask permission from the Chief of Customs. Second, it is continued by looking for land that meets the requirements to be used as agricultural land, namely by looking at soil color, type, tree size, and slope. Another preparation is preparing white chicken eggs and chicken bile for the traditional land clearing ceremony (vumpoyu) that will be carried out. The important thing discussed in the customary council meeting is determining the right time to clear agricultural land and carry out traditional ceremonies, this can be seen based on the calendar that coincides in June called bula karamba.

It is believed that June approaches summer which eases the process of clearing shrubs and so on; $b$ ) traditional ceremonies, traditional ceremonies are sacred activities. The Kaili da'a people believe that by carrying out traditional ceremonies the gods will help and protect during the land management process. The people of the Kaili $d a^{\prime} a$ tribe also believe that the surrounding environment is controlled by spirits called peu or wiyata, both in the forest, on land, and in waters. Therefore, everyone who will manage the environment must be careful and ask permission from the gods through traditional ceremonies; c) for the Kaili da' $a$ tribe, traditional ceremonies are a means of communication between humans and the supernatural. So the traditional ceremony must be carried out since starting activities from cutting wood, opening new land, until harvesting is finished. If not, there will be natural disasters/calamities as a karampua curse, due to mistakes or deficiencies in performing traditional ceremonies. The Kaili $d a^{\prime} a$ tribe adheres to customary rules and obeys the customary leader.

http://ijstm.inarah.co.id 


\section{2) Land clearing}

The first way to manage agricultural land is by clearing land. Another term for land clearing is land clearing or which means land clearing. The Kaili da'a people have unwritten rules but they obey them. The enforcement of this customary law makes the community live in harmony and security. Related to customary regulations, the Kaili $d a^{\prime} a$ tribe will leave their land after harvesting for 5-10 years to restore soil fertility. If more than 10 years then the land becomes less fertile and it is believed that the god of the land was angry, because the land never rested. After the soil has rested, the soil will naturally be fertile again. The Kaili da' $a$ tribe also believes that the forest environment is guarded by the guardian of the puenggayu wood or the wood god or called anitularangkayu, then the wood god is divided into three, namely; Dewa Yalarawa who guarded the top of the tree, Dewa Dandiya who guarded the middle of the tree and Dewa Suluvaeni who guarded the bottom of the tree. Thus, everyone who is going to cut wood must pay close attention to the traditional ceremony of clearing forests/land. In addition to the traditional ceremonies performed by farmers in particular, there are also ceremonies performed as a complement to the ceremony, among others, by looking at the stars by counting the months in the sky [13].

The people of the Kaili da'a tribe when opening agricultural land with rituals (pakabue) of land selection or vumpoyu by slaughtering white chickens then letting the chicken's blood drip on the ground then providing a pan filled with eggs, chicken bile then uma ramaya asks for help showing ova / land that can be managed for agricultural land, the way the eggs that have been provided are cracked, if the contents of the eggs turn brownish-black, it indicates the land is not good for cultivation. The Kaili da' $a$ tribe believes that the ancestral forest dwellers and the gods did not permit to manage the land into agricultural land. The selection of land to be opened as agricultural land is limited to three places, provided that the contents of the egg are yellow. If the contents of the eggs are yellow then the forest can be used as agricultural land. But if up to three egg containers are not yellow, the community must perform an annual ceremony sambulugana to apologize, make amends, and thank the ancestors and gods. Activities to open agricultural land can be carried out individually or in cooperation depending on the area or narrowness of the land, the weight or lightness of the work. This cooperative group is called the sipangava usually consists of ten to twenty people. Through this cooperation will make harmony within the Kaili $d a$ 'a Tribe community. In addition to traditional ceremonies, there are physical characteristics that must be fulfilled in determining agricultural land, namely as follows: The soil is brownishblack, the soil is loose, there are broad-leaf plants, and there are large trees and lush leaves.

\section{3) Land Piracy}

The Kaili da' $a$ tribe in land piracy activities is carried out in cooperation and helping each other. Rice fields are called nopipada. Land plowing is the process of cultivating the land to make it softer and looser. Land plowing also aims to break up chunks of soil so that the soil becomes smoother and looser. The Kaili da' $a$ tribe traditionally plowed land, namely by using cow labor. One of the simpler tools for piracy is the hacksaw. This tool functions to cut and reverse the soil to be cultivated. Based on the direction of the cut ground, there are two kinds of plows, namely the abrasive plow which can reverse the ground in one direction, and the double plow which can reverse the ground in two directions (to the right and the left).

The plowing stage is the stage of managing agricultural land before the first plant seeds are planted. In this process, the owner of the agricultural land is obliged to read a prayer to avoid disasters, be they disasters that befall the crops or disasters that befall the landowners. This needs to be done because all agricultural crop pests are believed to originate from incarnations of spirits or spirits who are not respected by certain ceremonies. If not done, spirits will incarnate, frustrate and destroy human life. As for the ritual process before planting the first seeds, namely pantilovu, namely the activity of asking for prayers or called sambulu gana (prayer bridges) so that during the work process they are kept away from plant pests. As for what is needed in this ritual is betel leaf, areca nut, betel lime, tobacco and goat. 


\section{4) Soil scratching}

Soil management by means of ripping is by digging the soil at a shallow depth and producing a smooth, flat surface ready for planting. Scouring uses a hoe to break down hard lumps of soil so that the soil structure and texture are smaller and smoother, and ready for planting. Before milling, fertilize first so that the fertilizer is mixed with the soil so that it is useful for improving soil nutrients. In the process of sowing fertilizer, a prayer is read with the hope that the fertilizer that is sown will fertilize the soil and the process of renewal work will go well. If the fertilization process does not read prayers they believe that the fertilizer is not fertilizing and there are problems such as animals getting sick before the process starts, plants will be attacked by pests, crop failure, etc. The updating process still uses traditional tools such as a hoe and pajeko which are pulled by two buffaloes.

\section{5) Basic Fertilization}

Basic fertilization is an effort to improve the quality of soil fertility. The use of organic fertilizers is the right way to maintain soil fertility. Organic matter has an important role as a material to trigger soil fertility, both directly as a nutrient supply for autotrophic organisms (plants) as well as a source of energy for heterotrophic organisms (fauna and soil microorganisms) [14]. Increasing soil biological activity will encourage improvement in soil fertility, physical, chemical, and biological soil fertility. Improvement of the physical, chemical, and biological characteristics of the soil in line with the plant requirements of the target plant will be able to improve plant growth and production.Based on this statement, it is clear that organic fertilization can increase soil fertility, either directly or indirectly. With organic fertilization, worms and micro-organisms in the soil can live and reproduce which will then support soil improvement both biologically, physically, and chemically. When compared with chemical fertilization, soil fertility does not last long because micro-organisms and earthworms cannot develop properly. This is by the local wisdom of the Kaili da'a Tribe who fertilizes with organic fertilizers. This organic fertilizer is made by you. Organic fertilizers that are made are manure and manure from leaves. Manure using goat, chicken, and cow dung. The process of making manure uses a hoe, the method is to mix animal manure with kasem (sawdust), then cover it with a tarpaulin so that it is not exposed to rainwater, then leave for 2-3 weeks, after which the fertilizer is ready for use on agricultural land. The process of making organic fertilizer from leaves uses dry leaves and wet leaves (fresh leaves that are old but not yet yellow). Then prepare the loose soil, that chop the leaves and mix and then cover, let stand for 6 weeks.

In making fertilizer, the Kaili $d a^{\prime} a$ tribe also carries out a traditional ritual called pounjulovu or made prayer water (sabolu) with the god of soil fertility humus or fertility soil. They believe that pouring water and praying to God will provide fertile soil and the fertilizer-making process will be successful. The Kaili da' $a$ tribe uses organic fertilizers to protect the soil and plants, they avoid using chemical fertilizers because they think that using chemical fertilizers continuously and excessively will damage the soil and will make the soil infertile. From the results of the discussion related to the management of agricultural land by the Kaili da' $a$ Tribe, it can be seen that the Kaili $d a^{\prime} a$ Tribe maintains the preservation of Nature. In their activities managing the agricultural land of the Da'a Tribe using traditional tools, because they believe that traditional tools will not destroy soil nutrients. Likewise, in terms of fertilization, they use organic fertilizers; the Kaili da'a tribe maintains harmony and social order between humans and humans, humans and their environment as well as humans and ancestors. The Kaili da' $a$ tribe has a philosophy of life, namely Tanah Indoku-Ummaku Langi(Land is my mother, and heaven is my father). The meaning of this philosophy is that land is a natural resource that is very important in giving life. Therefore, the local wisdom of the Kaili da'a Tribe must be maintained to preserve the environment and the sustainability of natural resources in the future. In addition, the moral values that are still very thick in the Kaili da'a Tribe are obedience to traditional leaders, adherence to customary law, still, highly uphold values inherited from their ancestors, are very careful in making decisions and acting, love nature, not being greedy (as evidenced by the way he manages nature), mutual help and cooperation. This shows that the values of local wisdom in an area must be maintained and maintained. 


\section{CONCLUSION}

Based on the research results, it can be concluded that the management of agricultural land for the Kaili $d a^{\prime} a$ Tribe in Dombu Village is carried out traditionally in accordance with local wisdom. The Kaili da' $a$ tribe has a philosophy of life which reads Tanah Indoku-Ummaku Langi (Land is my mother and sky is my father) that land is a very important natural resource. Almost all aspects of life are related to land, humans were created from the ground and will return to the land.

\section{REFERENCES}

[1] Z. Petrovic, D. Manojlovic, and V. Jovic, "Legal protection of land from pollution," Ekon. Poljopr., 2014, doi: 10.5937/ekopolj1403723p.

[2] S. Supriyadi, J. Winarno, M. R. R., and S. Sumani, "Penerapan Analisis Kesesuaian Lahan Untuk Pengembangan Tanaman Janggelan Di Kabupaten Pacitan," SEMAR (Jurnal Ilmu Pengetahuan, Teknol. dan Seni bagi Masyarakat), 2018, doi: 10.20961/semar.v6i1.20876.

[3] Y. Ngongo, Irawan, and U. Haryati, "Conservation agriculture in semi-arid area of Indonesia: Lesson learnt to increase maize production and farmers' awareness on environmental friendly land management," 2021, doi: 10.1088/1755-1315/648/1/012030.

[4] N. Munir, A. Kiani, and A. Baig, "Climate Change and Food Security in Pakistan: A Time Series Analysis," Glob. Econ. Rev., 2016, doi: 10.31703/ger.2016(i-i).05.

[5] G. M. PRICILIA, "Penerapan Model Pembelajaran Berbasis Kearifan Lokal Berorientasi Karakter Terhadap Kemampuan Menulis Berbahasa Inggris Mahasiswa di IPTS,” J. Educ. Dev., 2019, doi: 10.37081/ed.v7i3.1137.

[6] D. Septiwiharti, "Budaya Sintuvu Masyarakat Kaili di Sulawesi Tengah [The Sintuvu Culture of The Kaili People in Central Sulawesi]," Naditira Widya, 2020, doi: 10.24832/nw.v14i1.419.

[7] S. Handayani and N. Pratiwi, "Health Seeking Behaviour pada Persalinan Suku Kaili Da'a di Desa Wulai Kabupaten Mamuju Utara sulawesi Barat,” Bul. Penelit. Sist. Kesehat., 2016.

[8] J. Abdul Latief, I. Listiqowati, and A. Abd Muis, "Development of Teaching Material Supplement for Geography Subject Based on Local Wisdom of Kaili Da'a in Sigi Regency, Central Sulawesi," Int. J. Educ. Res. Soc. Sci., 2021, doi: 10.51601/ijersc.v2i2.77.

[9] L. Hamdani, “Zakat Blockchain: A Descriptive Qualitative Approach,” EkBis J. Ekon. dan Bisnis, 2020, doi: 10.14421/ekbis.2020.4.2.1270.

[10] L. Lutfi, M. Akbar, and M. Marzuki, "Muslim Society Perception of The Unregistered Divorce," Int. J. Contemp. Islam. LAW Soc., 2020, doi: 10.24239/ijcils.vol2.iss2.21.

[11] D. L. Setyowati, A. I. Benardi, R. Widyastiti, and T. Arsal, "Farmer' s Local Wisdom In Agricultural Land Conservation of Dieng Area," Komunitas Int. J. Indones. Soc. Cult., 2019.

[12] K. Prayoga, A. M. Riezky, A. R. Syuhada, and D. S. Prayoga, "Socio cultural and agricultural local wisdom by cetho indigenous community to preserve the nature," AGROMIX, 2020, doi: 10.35891/agx.v11i1.1843.

[13] Agus Waluwkow, Steven Sumolang, Neni Kumayas, Ihwal, Ardhie wynardhie, "Menggali Kearifan Lokal Kaitannya Dengan Konservasi Lingkungan Pada Masyarakat Donggala Khususnya Kaili Da'a di Sulawesi Tengah". Yogyakarta : Kepel Press, 2012.

[14] Subowo G. "Strategi Efisiensi Penggunaan Bahan Organik untuk Kesuburan dan Produktivitas Tanah Melalui Pemberdayaan Sumberdaya Hayati Tanah”. Jurnal Sumberdaya Lahan. Vol. 4. No. 1. ISSN 1907-0799. 2010. 